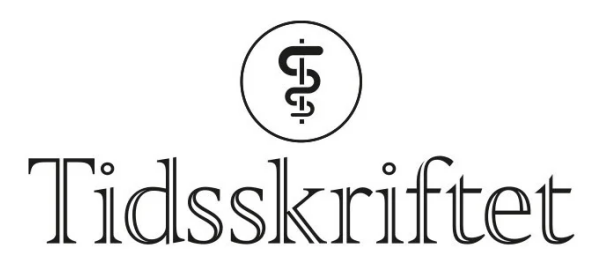

DEN NORSKE LEGEFORENING

\title{
Gunnar Alm Rosland
}

\author{
MINNEORD
}

ANSGAR BERG

\section{GOTTFRIED GREVE}

Department of Clinical Science

Faculty of Medicine

University of Bergen

and

Department of Heart Disease

Haukeland University Hospital

He has contributed to the concept and design, to data collection, analysis and interpretation, to the literature search, and to the drafting and revision of the manuscript.

Gottfried Greve, MD PhD, is a professor, senior consultant and head of section.

The author has completed the ICMJE form and declares no conflicts of interest.

\section{ASLE HIRTH}

\section{GUNNAR NORG ̊̊D}

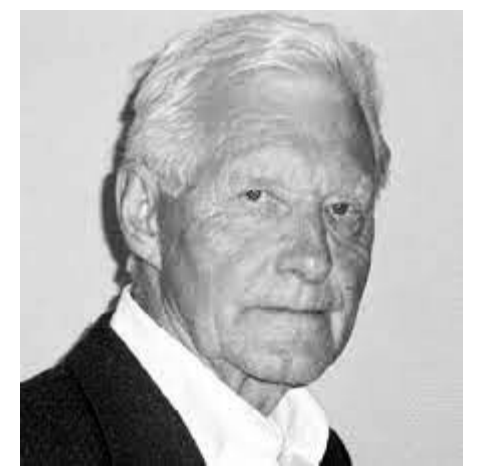

Gunnar Alm Rosland ble født 18.5.1933 og døde 16.7.2021.

Med Gunnar Rosland har Norge mistet en pioner innen hjertemedisinen. Han vokste opp i Eydehavn og beholdt hele livet det sørlandske lynnet, lavmælt og ydmyk, i møte med pasienter og kolleger. Etter medisinsk embetseksamen fra Universitetet i Bergen ble han spesialist i klinisk fysiologi. Han kom i 196o-årene til Haukeland og ble en av drivkreftene i oppbyggingen av Klinisk fysiologisk avdeling, i dag en del av Hjerteavdelingen. 
Gunnar var en svært dyktig lege og bidro i stor grad til utviklingen av den moderne hjertemedisinen. Han var vitebegjærlig, med en unik evne til å vurdere og ta i bruk nye metoder som han ivrig videreformidlet i fagmiljøet. Han var med på å utvikle og lage de første dialyseapparatene, lenge før de ble kommersielt tilgjengelige. Han var blant de første i Norge som startet med hjertekateterisering av voksne og barn. Han hadde unik tredimensjonal forståelse av hjertet og av hemodynamikk.

Gunnar ble tidlig betrodd ansvaret for barn med medfødt hjertefeil, og barnekardiologi ble hans særinteresse til han gikk av med pensjon i 2003. Også barn fikk glede av hans ferdigheter i invasiv kardiologi, og da ekkokardiografien gjorde sitt inntog, tok han teknikken raskt i bruk. Lenge før andre så behovet, startet han oppfølging av voksne med alvorlig hjertefeil. Gunnar hadde en bred utenlandsk kontaktflate som han benyttet flittig for å holde seg og fagmiljøet i fronten av fagutviklingen. Uten Gunnars innsats ville barnehjertemedisinen hatt en mye langsommere utvikling i Norge. For sin banebrytende innsats ble han hedret med Norsk cardiologisk selskaps hederspris og Kongens fortjenstmedalje i gull.

Gunnar var i sin praksis flink til å trekke oss yngre kollegaer med. Med stor tålmodighet ga han oss tillit og tilbakemeldinger som fremmet læring og mestring. Hans tilstedeværelse ga virkelig mening til begrepet mester-svenn-opplæring.

Men Gunnar var ikke bare en fremragende lege. Han var samfunnsengasjert og alltid velorientert, med solid kunnskap innen mange felt. Han virket aldri påtrengende med sine kunnskaper, men ga enhver samtale noe ekstra. Sjelden hevet han stemmen, men ga klare beskjeder når urett ble begått. Han hadde stor menneskekunnskap. Han visste at livet kunne fare mindre pent med mennesker og møtte derfor alle med respekt. Det er mange pasienter med medfødt hjertefeil og deres familier som har fått god hjelp av Gunnar, også der livet ikke stod til å redde.

Våre tanker går til Randi, barn og barnebarn, som har mistet en omtenksom ektemann, far og bestefar. Vi lyser fred over Gunnar Alm Roslands minne.

På vegne av kollegaer ved Hjerteavdelingen og Barne- og ungdomsklinikken, Haukeland universitetssjukehus

Publisert: 6. september 2021. Tidsskr Nor Legeforen. DOI: 10.4045/tidsskr.21.0561

(C) Tidsskrift for Den norske legeforening 2023. Lastet ned fra tidsskriftet.no 26. april 2023. 